\title{
Why has it been so difficult to prove the efficacy of alpha-I-antitrypsin replacement therapy? Insights from the study of disease pathogenesis
}

This article was published in the following Dove Press journal:

Drug Design, Development and Therapy

16 August 2011

Number of times this article has been viewed

\section{Jennifer A Dickens \\ David A Lomas}

Department of Medicine, University of Cambridge, Cambridge Institute for Medical Research, Wellcome Trust/ MRC Building, Cambridge, UK
Correspondence: David Lomas Department of Medicine, University of Cambridge, Cambridge Institute for Medical Research, Wellcome Trust/ MRC Building, Hills Road,

Cambridge, CB2 OXY, UK

Tel +44 I 2237628 I8

$\mathrm{Fax}+44 \quad 1223336827$

Email dall6@cam.ac.uk
Abstract: Alpha-1-antitrypsin is the most abundant circulating protease inhibitor. It is mainly produced by the liver and secreted into the circulation where it acts to prevent excessive proteolytic damage in the lungs by the enzyme neutrophil elastase. The most common severe deficiency allele is the $\mathrm{Z}$ mutation, which causes the protein to self-associate into ordered polymers. These polymers accumulate within hepatocytes to cause liver damage. The resulting lack of circulating $\alpha_{1}$-antitrypsin predisposes the $\mathrm{Z}$ homozygote to proteolytic lung damage and emphysema. Other pathways may also contribute to the development of lung disease. In particular, polymers of $\mathrm{Z} \alpha_{1}$-antitrypsin can form within the lung where they act as a proinflammatory stimulus that may exacerbate protease-mediated lung damage. Researchers recognized in the 1980 s that plasma $\alpha_{1}$-antitrypsin levels could be restored by intravenous infusions of purified human protein. Alpha-1-antitrypsin replacement therapy was introduced in 1987 but subsequent clinical trials have produced conflicting results, and to date there remains no widely accepted clinical evidence of the efficacy of $\alpha_{1}$-antitrypsin replacement therapy. This review addresses our current understanding of disease pathogenesis in $\alpha_{1}$-antitrypsin deficiency and questions why this treatment in isolation may not be effective. In particular it discusses the possible role of $\alpha_{1}$-antitrypsin polymers in exacerbating intrapulmonary inflammation and attenuating the efficacy of $\alpha_{1}$-antitrypsin replacement therapy.

Keywords: $\alpha_{1}$-antitrypsin deficiency, emphysema, augmentation therapy

\section{Introduction}

Alpha-1-antitrypsin deficiency was first described in 1963 by Laurell and Eriksson ${ }^{1}$ who noted the absence of the $\alpha_{1}$ band on serum protein electrophoresis in 5 out of 1500 samples. Three of these individuals had developed early onset emphysema. The association with liver disease was reported 6 years later by Sharp and colleagues ${ }^{2}$ and more recently $\alpha_{1}$-antitrypsin deficiency has been associated with the development of bronchiectasis, ${ }^{3}$ asthma, ${ }^{4}$ vasculitis, ${ }^{5}$ and panniculitis. ${ }^{6}$

Alpha-1-antitrypsin is a member of the serine protease inhibitor or serpin superfamily of proteins. It is secreted mainly by hepatocytes but also by lung and gut epithelial cells, ${ }^{7-9}$ neutrophils ${ }^{10}$ and alveolar macrophages, ${ }^{11}$ and is present in the plasma at a concentration of 1.5-3.5 g/L (when measured by an immunodiffusion method). Circulating plasma $\alpha_{1}$-antitrypsin is a 394-amino-acid, $52 \mathrm{kDa}$, acute-phase glycoprotein that acts to inhibit the proteolytic enzyme neutrophil elastase. This enzyme is released at sites of inflammation and, if unregulated, causes proteolytic damage to connective tissue. This is particularly important in the lung as it is persistently exposed to inhaled pro-inflammatory stimuli. 
Most individuals carry the normal "M" allele of $\alpha_{1}$-antitrypsin. However more than 100 different alleles have been identified to date, of which over 30 affect either the amount or the function of the molecule in vivo. Most $\alpha_{1}$-antitrypsin variants are named according to their migration during isoelectric focusing, variants $\mathrm{A}-\mathrm{L}$ running faster and $\mathrm{N}-\mathrm{Z}$ slower than the normal " $\mathrm{M}$ " protein. The most common severe deficiency mutant is the "Z" (Glu $\left.{ }^{342} \mathrm{Lys}\right)$ allele which is thought to have originated in northern Europe (where the prevalence is $2 \%-4 \%)^{12,13}$ and is also seen as the predominant severe mutation in North America, Australia, and New Zealand. ${ }^{14}$ Other important disease-causing alleles include Siiyama ( $\left.\mathrm{Ser}^{53} \mathrm{Phe}\right)$, prevalent in Japan, ${ }^{15}$ and Mmalton $\left(\Delta^{52} \mathrm{Phe}\right)$ which is the most common rare deficiency allele seen in Sardinia ${ }^{16}$ and which has been reported sporadically in the UK and Canada. Table 1 details the characteristics of recognized deficiency and null ${ }^{17}$ alleles.

Individuals with abnormal alleles have a plasma deficiency due to a lack of secretion of $\alpha_{1}$-antitrypsin from hepatocytes. ${ }^{18}$ The severity of the plasma deficiency is predictable with the $\mathrm{S}$ allele reducing plasma levels to $60 \%$ of normal and the $\mathrm{Z}$ allele to $10 \%$ of normal; thus an SZ compound heterozygote has plasma levels that are $40 \%$ of normal. The resulting lack of elastase inhibition contributes to tissue destruction and panlobular emphysema, particularly in the inflamed lungs of smokers who have a significantly reduced life expectancy when compared with never smokers. ${ }^{19}$ Indeed $\alpha_{1}$-antitrypsin deficiency is the only known genetic cause of emphysema and is found in $1 \%-2 \%$ of all cases of chronic obstructive pulmonary disease (COPD) ${ }^{20}$

Alpha-1-antitrypsin augmentation therapy was developed to replace the deficient circulating protein and so ameliorate the progression of the associated emphysema. ${ }^{21}$ It is now widely used in many countries for individuals with severe deficiency of circulating $\alpha_{1}$-antitrypsin. However no randomized controlled studies have convincingly shown it to be an effective strategy in slowing the progression of lung disease or reducing mortality. ${ }^{22}$ This may be due to a lack of suitably powered studies although the pathogenesis of this condition is complex which may mean that this approach has only limited efficacy. This review considers the factors that may mitigate against the complete or partial effectiveness of $\alpha_{1}$-antitrypsin augmentation therapy.

\section{Pathogenesis of disease: $\alpha_{1}$-antitrypsin function, processing and polymerization}

Normal " $M$ " $\alpha_{1}$-antitrypsin is secreted from the liver and acts as a very effective protease inhibitor. It binds neutrophil elastase via a methionine residue at position 358 , on the reactive center loop of the protein (Figure 1). After binding, the enzyme is translocated from one end of the protein to the other in association with insertion of the reactive loop into $\beta$-sheet A. This forms a covalently linked complex of enzyme and inhibitor that is cleared from the circulation.

The Z (Glu342 Lys), Siiyama, and probably many other alleles result in a delay in folding in the secretory pathway of hepatocytes. ${ }^{23,24}$ Much of the protein fails to fold and is "timed out" by the folding sensor manosidase I. ${ }^{25}$ This material is a substrate for endoplasmic reticulum (ER) associated degradation and is destroyed by the proteasome. ${ }^{26-28}$ A proportion is folded correctly, trafficked through the endoplasmic reticulum and Golgi apparatus and secreted into the circulation. The remainder is folded to a near-native conformation but does not achieve the native state. The Glu342 Lys mutation results in an expansion of $\beta$-sheet $A$ and perturbation of the $F$ helix to form an intermediate that we have termed $\left(\mathrm{M}^{*}\right) \cdot{ }^{29}$ The reactive center loop of a second $\alpha_{1}$-antitrypsin molecule can then bind to this intermediate, forming a dimer that extends to form a polymer. ${ }^{18}$ The resultant polymer has an ordered, repeating structure but no anti-neutrophil elastase activity, because the reactive loop that is central to the polymerization process is buried in $\beta$-sheet $\mathrm{A}$ of another molecule (Figure 1). These polymers are sequestered within the ER of hepatocytes where they form diastase resistant, periodic acid-Schiff stain positive inclusions, which are associated with liver disease (Figure 2). ${ }^{18}$ The $\mathrm{Z} \alpha_{1}$-antitrypsin that is correctly folded and trafficked through the secretory pathways still has the propensity to form polymers. These have been identified in the lung ${ }^{30}$ and in biopsies from the $\operatorname{skin}^{31}$ and kidneys ${ }^{32}$ from $\mathrm{Z} \alpha_{1}$-antitrypsin homozygotes.

Study of the consequences of abnormally folded protein accumulation in hepatocytes has helped shed light on the mechanism of this gain-of-function toxicity that causes $\alpha_{1}$-antitrypsin deficiency associated liver disease. The presence of polymers of $\alpha_{1}$-antitrypsin within the ER causes ER stress. This is defined as a state in which unfolded proteins accumulate and aggregate within the ER, perturbing normal ER function. Misfolded protein accumulation triggers the unfolded protein response (UPR); resident ER chaperones involved in protein folding are upregulated and translation of the abnormal protein is downregulated to restore homeostasis. ${ }^{33}$ An excess of protein traffic, for example following viral infection of a cell, triggers the ER overload response (EOR), resulting in calcium-dependent NF- $\kappa \mathrm{B}$ activation. ${ }^{34}$ 
Table I Pathogenic alleles that cause $\alpha_{1}$-antitrypsin deficiency

\begin{tabular}{|c|c|c|c|c|}
\hline Variant & Mutation & Molecular basis of disease & Clinical features & Epidemiology \\
\hline \multicolumn{5}{|l|}{ Deficiency alleles } \\
\hline$\rho^{98}$ & $\mathrm{Arg}^{39} \mathrm{Cys}$ & $\begin{array}{l}\text { Protein misfolding; able to form } \\
\text { heteropolymers. } \\
\text { Reduced serum protein }\end{array}$ & No clear disease association & $\begin{array}{l}\text { Disease only reported in } \\
\text { compound heterozygotes }\end{array}$ \\
\hline King's 99 & Hisp $p^{334} A s p$ & $\begin{array}{l}\text { Rapid polymerization in hepatocyte } \\
\text { endoplasmic reticulum, delayed } \\
\text { secretion }\end{array}$ & $\begin{array}{l}\text { Neonatal jaundice. } \\
\text { Presumed high risk of } \\
\text { emphysema in homozygote/ } \\
\text { compound heterozygote }\end{array}$ & Case report \\
\hline Mheerlen $^{100}$ & Pro $^{369}$ Leu & $\begin{array}{l}\text { Retained in the endoplasmic } \\
\text { reticulum, none secreted }\end{array}$ & $\begin{array}{l}\text { High risk of emphysema } \\
\text { in homozygotes/compound } \\
\text { heterozygotes. } \\
\text { Unknown liver disease risk }\end{array}$ & Case report \\
\hline Mmalton ${ }^{101}$ & $\begin{array}{l}\Delta^{52} \mathrm{Phe} \\
(\mathrm{M} 2 \text { variant })\end{array}$ & $\begin{array}{l}\text { Intracellular degradation and } \\
\text { polymerization; low serum } \\
\text { concentration }\end{array}$ & $\begin{array}{l}\text { Well established association } \\
\text { with liver disease and } \\
\text { emphysema in homozygotes }\end{array}$ & $\begin{array}{l}\text { Most common rare } \\
\text { deficiency allele in Sardinia; }{ }^{16} \\
\text { seen sporadically in the UK } \\
\text { and Canada }\end{array}$ \\
\hline $\begin{array}{l}\text { Mmineral } \\
\text { springs }\end{array}$ & Gly ${ }^{67} \mathrm{Glu}$ & $\begin{array}{l}\text { Abnormal post-translational } \\
\text { biosynthesis but no polymerization; } \\
\text { low serum concentration }\end{array}$ & Emphysema in homozygotes & $\begin{array}{l}\text { Unusual as described in a } \\
\text { Afro-Caribbean individual } \\
\text { in the United States }\end{array}$ \\
\hline Mnichinan ${ }^{103}$ & $\begin{array}{l}\Delta^{52} \mathrm{Phe} \text { and } \mathrm{Gly} \\
\text { Arg }\end{array}$ & $\begin{array}{l}\text { Intracellular polymerization in } \\
\text { hepatocytes and plasma deficiency }\end{array}$ & $\begin{array}{l}\text { Risk of liver disease and } \\
\text { emphysema }\end{array}$ & $\begin{array}{l}\text { Case report (Japanese family } \\
\text { with consanguineous origin) }\end{array}$ \\
\hline Mpalermo ${ }^{104}$ & $\Delta^{51}$ Phe & Serum deficiency & $\begin{array}{l}\text { High risk of emphysema } \\
\text { in homozygotes }\end{array}$ & Case report \\
\hline Mprocida ${ }^{105}$ & Leu'Pro & $\begin{array}{l}\text { Unstable protein structure leading } \\
\text { to intracellular degradation; reduced } \\
\text { catalytic activity of circulating protein }\end{array}$ & $\begin{array}{l}\text { High risk of emphysema } \\
\text { in homozygotes }\end{array}$ & Case report \\
\hline $\begin{array}{l}\text { Mvall d'hebron }{ }^{106} \\
(=\text { Mwurzburg) }\end{array}$ & Pro $^{369} \mathrm{Ser}$ & $\begin{array}{l}\text { Retained in the endoplasmic } \\
\text { reticulum, none secreted }\end{array}$ & $\begin{array}{l}\text { Presumed risk of emphysema } \\
\text { in homozygotes/compound } \\
\text { heterozygotes; } 50 \% \text { normal } \\
\text { serum } \alpha_{1} \text {-antitrypsin level } \\
\text { in M/vall d'hebron (/wurzburg) } \\
\text { heterozygotes }\end{array}$ & $\begin{array}{l}\text { Case reports from Spain } \\
\text { and Germany }\end{array}$ \\
\hline Mvarallo 107 & $\begin{array}{l}\Delta^{41-51} \text {, replaced with } \\
22 \text { bp sequence } \\
\text { creating stop codon } \\
\text { at } 70-71\end{array}$ & Unknown intracellular defect & $\begin{array}{l}\text { Presumed risk of emphysema } \\
\text { in homozygotes/compound } \\
\text { heterozygotes; } 50 \% \text { normal } \\
\text { serum } \alpha_{1} \text {-antitrypsin level } \\
\text { in M/Mvarallo heterozygote }\end{array}$ & Case report \\
\hline Pittsburgh ${ }^{108}$ & $\mathrm{Met}^{358} \mathrm{Arg}$ & Function altered to an antithrombin & Fatal bleeding disorder & Case report \\
\hline $\begin{array}{l}\text { Plowell } \\
\text { (=QO Cardiff) } \\
\text { and Pduarte }\end{array}$ & $\begin{array}{l}\mathrm{Asp}^{256} \mathrm{Val} \\
\text { (MI and } \mathrm{M} 4 \\
\text { alleles respectively) }\end{array}$ & $\begin{array}{l}\text { Intracellular degradation and plasma } \\
\text { deficiency }\end{array}$ & $\begin{array}{l}\text { Increased risk of emphysema } \\
\text { in Z/QO compound } \\
\text { heterozygotes }\end{array}$ & Case report \\
\hline S & $\mathrm{Glu}^{264} \mathrm{Val}$ & $\begin{array}{l}\text { Protein misfolding and reduced } \\
\text { secretion; able to form } \\
\text { heteropolymers with } Z \alpha_{1} \text {-antitrypsin }\end{array}$ & $\begin{array}{l}\text { Emphysema seen in SZ } \\
\text { heterozygotes but less } \\
\text { severe than in ZZ.'12 } \\
\text { Cirrhosis reported in SZ } \\
\text { heterozygotes }^{113}\end{array}$ & $\begin{array}{l}\text { Most common deficiency } \\
\text { variant. Carrier frequency: } \\
\text { I:5 Northern Europe } \\
\text { I:30 USA } \\
\text { I:23 Australian Caucasian } \\
\text { I:26 New Zealand Caucasian } \\
\text { Rare/non-existent in Asia, } \\
\text { Africa and Australian } \\
\text { Aboriginals }{ }^{1 / 4}\end{array}$ \\
\hline Siiyama ${ }^{115}$ & Ser ${ }^{53} \mathrm{Phe}$ & $\begin{array}{l}\text { Intracellular degradation and } \\
\text { polymerization; low serum } \\
\text { concentration }\end{array}$ & $\begin{array}{l}\text { Liver disease and } \\
\text { emphysema in homozygotes }\end{array}$ & $\begin{array}{l}\text { Rare, but most common } \\
\text { deficiency allele in Japan }\end{array}$ \\
\hline Wbethesda ${ }^{116}$ & $\mathrm{Ala}^{336} \mathrm{Thr}$ & $\begin{array}{l}\text { Intracellular degradation, } \\
\text { serum levels } 50 \% \text { normal }\end{array}$ & $\begin{array}{l}\text { Risk of liver disease } \\
\text { and emphysema in } \\
\text { compound heterozygotes }\end{array}$ & Case report \\
\hline
\end{tabular}


Table I (Continued)

\begin{tabular}{|c|c|c|c|c|}
\hline Variant & Mutation & Molecular basis of disease & Clinical features & Epidemiology \\
\hline Ybarcelonal17 $^{117}$ & $\begin{array}{l}\text { Asp }{ }^{256} \mathrm{Val} \text { and } \\
\text { Pro }^{391} \mathrm{His}\end{array}$ & $\begin{array}{l}\text { Unknown intracellular defect; } \\
\text { very low serum protein }\end{array}$ & $\begin{array}{l}\text { Severe emphysema } \\
\text { reported in homozygote }\end{array}$ & Case report \\
\hline Z & Glu $^{342}$ Lys & $\begin{array}{l}\text { Intracellular degradation and } \\
\text { polymerization; low serum } \\
\text { concentration }\end{array}$ & $\begin{array}{l}\text { Homozygotes: well } \\
\text { established association with } \\
\text { liver disease and emphysema. } \\
\text { MZ heterozygotes may be } \\
\text { more susceptible to airflow } \\
\text { obstruction }^{118} \text { and chronic } \\
\text { liver disease }\end{array}$ & $\begin{array}{l}\text { Commonest severe } \\
\text { deficiency variant. Carrier } \\
\text { frequency: } \\
\text { I:27 Northern Europe } \\
\text { I:83 USA } \\
\text { I:75 Australian Caucasian } \\
\text { I:46 New Zealand Caucasian } \\
\text { Not seen in China, Japan, } \\
\text { Korea, Malaysia, Northern } \\
\text { and Western Africa'"l }\end{array}$ \\
\hline $\begin{array}{l}\text { Zausburg } \\
(=\text { Ztun })^{|20,| 2 \mid}\end{array}$ & $\begin{array}{l}\text { Glu }^{342} \text { Lys } \\
\text { (M2 variant) }\end{array}$ & $\begin{array}{l}\text { Intracellular degradation and } \\
\text { polymerization; low serum } \\
\text { concentration }\end{array}$ & $\begin{array}{l}\text { Liver disease and emphysema } \\
\text { in homozygotes/compound } \\
\text { heterozygotes }\end{array}$ & Case report \\
\hline Zwrexham $^{122}$ & $\begin{array}{l}\text { Ser }^{-19} \text { Leu and } \mathrm{Glu}^{342} \\
\text { Lys ( } \mathrm{Z} \text { mutation) }\end{array}$ & $\begin{array}{l}\text { Poor expression, low serum } \\
\text { concentration }\end{array}$ & $\begin{array}{l}\text { Emphysema reported in } \\
\text { compound Z/Zwrexham } \\
\text { compound heterozygotes. } \\
\text { Unclear whether Ser-19 Leu } \\
\text { would cause disease in } \\
\text { absence of Z mutation }\end{array}$ & Case report \\
\hline \multicolumn{5}{|l|}{ Null (QO) alleles } \\
\hline QO Bellingham ${ }^{123}$ & Lys $^{217}$ stop codon & No detectable $\alpha_{1}$-antitrypsin mRNA & $\begin{array}{l}\text { High risk of emphysema in } \\
\text { homozygotes/compound } \\
\text { heterozygotes }\end{array}$ & Case report \\
\hline QO Bolton ${ }^{124}$ & $\begin{array}{l}\Delta \mathrm{IbpPro}^{362} \\
\text { causing stop codon } \\
\text { at } 373\end{array}$ & $\begin{array}{l}\text { Truncated protein; intracellular } \\
\text { degradation and no secreted protein }\end{array}$ & $\begin{array}{l}\text { High risk of emphysema in } \\
\text { homozygotes/compound } \\
\text { heterozygotes }\end{array}$ & Case report \\
\hline QO Cairo ${ }^{125}$ & Lys $^{259}$ stop codon & Unknown intracellular defect & $\begin{array}{l}\text { High risk of emphysema in } \\
\text { homozygotes/compound } \\
\text { heterozygotes }\end{array}$ & Case report \\
\hline QO Clayton ${ }^{126}$ & $\begin{array}{l}\text { Pro }^{362} \text { ins } C \\
\text { causing stop codon } \\
\text { at } 376\end{array}$ & $\begin{array}{l}\text { Truncated protein; intracellular } \\
\text { degradation and no secreted protein }\end{array}$ & $\begin{array}{l}\text { High risk of emphysema in } \\
\text { homozygotes/compound } \\
\text { heterozygotes }\end{array}$ & Case report \\
\hline $\begin{array}{l}\text { QO Devon } \\
\text { (=QO Newport) }{ }^{122}\end{array}$ & $\begin{array}{l}\text { Gly }{ }^{115} \text { Ser and } \mathrm{Glu}^{342} \\
\text { Lys (Z mutation) }\end{array}$ & $\begin{array}{l}\text { Intracellular degradation and } \\
\text { polymerization; reduced serum } \\
\text { concentration }\end{array}$ & $\begin{array}{l}\text { Risk of emphysema and liver } \\
\text { disease in compound } \\
\text { heterozygotes. } \\
\text { Unclear whether Gly }{ }^{115} \mathrm{Ser} \\
\text { would cause disease in } \\
\text { absence of Z mutation }\end{array}$ & Case report \\
\hline $\begin{array}{l}\text { QO Granite } \\
\text { Falls }^{127}\end{array}$ & $\begin{array}{l}\Delta \mathrm{Ibp} T y r^{160} \\
\text { causing stop codon }\end{array}$ & No detectable $\alpha_{1}$-antitrypsin mRNA & $\begin{array}{l}\text { Severe emphysema reported } \\
\text { in Z compound heterozygote }\end{array}$ & Case report \\
\hline QO Hong Kong ${ }^{128}$ & $\begin{array}{l}\Delta 2 \text { bpLeu }{ }^{318} \\
\text { causing stop codon } \\
\text { at } 334\end{array}$ & $\begin{array}{l}\text { Truncated protein; intracellular } \\
\text { aggregation (no polymerization), } \\
\text { degradation and no secreted protein }\end{array}$ & $\begin{array}{l}\text { High risk of emphysema in } \\
\text { homozygotes/compound } \\
\text { heterozygotes }\end{array}$ & $\begin{array}{l}\text { Case reports (individuals } \\
\text { of Chinese descent) }\end{array}$ \\
\hline $\begin{array}{l}\text { QO Isola } \\
\text { di Procida }\end{array}$ & $\begin{array}{l}\Delta \mathrm{I} 7 \mathrm{~Kb} \text { inc. } \\
\text { exons II-V }\end{array}$ & No detectable $\alpha_{1}$-antitrypsin mRNA & $\begin{array}{l}\text { Emphysema reported in } \\
\text { Mprocida compound } \\
\text { heterozygote }\end{array}$ & Case report \\
\hline QO Lisbon ${ }^{104}$ & $\mathrm{Thr}^{68} \| \mathrm{le}$ & Truncated protein; not secreted & $\begin{array}{l}\text { High risk of emphysema } \\
\text { in homozygotes. } 50 \% \text { normal } \\
\text { serum } \alpha_{1} \text {-antitrypsin in M/QO } \\
\text { Lisbon heterozygotes }\end{array}$ & Case report \\
\hline $\begin{array}{l}\text { QO } \\
\text { Ludwisghafen }{ }^{130}\end{array}$ & $11 e^{92}$ Asn & $\begin{array}{l}\text { Disruption of tertiary structure; } \\
\text { intracellular degradation and no } \\
\text { detectable serum protein }\end{array}$ & $\begin{array}{l}\text { High risk of emphysema in } \\
\text { homozygotes/compound } \\
\text { heterozygotes }\end{array}$ & Case report \\
\hline
\end{tabular}

(Continued) 
Table I (Continued)

\begin{tabular}{|c|c|c|c|c|}
\hline Variant & Mutation & Molecular basis of disease & Clinical features & Epidemiology \\
\hline $\begin{array}{l}\text { QO Mattawa } \\
\text { (MI allele) })^{131} / \mathrm{QO} \\
\text { Ourém (M3 allele) }{ }^{132}\end{array}$ & $\begin{array}{l}\text { Leu }^{353} \text { Phe } \\
\text { causing stop codon } \\
\text { at } 376\end{array}$ & $\begin{array}{l}\text { Truncated protein; misfolding and } \\
\text { reduced serum levels }\end{array}$ & $\begin{array}{l}\text { Emphysema reported in } \\
\text { homozygotes }\end{array}$ & Case reports \\
\hline QO Riedenburg ${ }^{133}$ & $\begin{array}{l}\text { Whole gene } \\
\text { deletion }\end{array}$ & No gene expression & $\begin{array}{l}\text { High risk of emphysema in } \\
\text { homozygotes/compound } \\
\text { heterozygotes }\end{array}$ & Case report \\
\hline $\begin{array}{l}\text { QO } \\
\text { Saarbueken }{ }^{104}\end{array}$ & $\begin{array}{l}1158 \text { dupC } \\
\text { causing stop codon } \\
\text { at } 376\end{array}$ & Truncated protein; not secreted & $\begin{array}{l}\text { High risk of emphysema in } \\
\text { homozygotes. } \\
50 \% \text { normal serum } \\
\alpha_{1} \text {-antitrypsin in } M / Q O \\
\text { Saarbueken heterozygotes }\end{array}$ & Case report \\
\hline $\begin{array}{l}\text { QO } \\
\text { Trastevere }{ }^{134}\end{array}$ & Try ${ }^{194}$ stop codon & $\begin{array}{l}\text { Reduced mRNA, degradation of } \\
\text { truncated protein; not secreted }\end{array}$ & $\begin{array}{l}\text { Emphysema reported in } \\
\text { compound heterozygote }\end{array}$ & Case report \\
\hline QO West ${ }^{135}$ & $\begin{array}{l}\Delta \text { Gly }^{164} \\
\text { Lys }^{191}\end{array}$ & $\begin{array}{l}\text { Aberrant mRNA splicing, } \\
\text { intracellular degradation and } \\
\text { no detectable serum protein }\end{array}$ & $\begin{array}{l}\text { Emphysema reported in } \\
\text { compound heterozygote }\end{array}$ & Case report \\
\hline
\end{tabular}

It is striking that polymers of $\alpha_{1}$-antitrypsin do not activate the UPR in the absence of a second "hit" such as heat or accumulation of other misfolded proteins; this is likely to be due to the ordered nature of the polymers. ${ }^{35}$ They do however activate the EOR. ${ }^{36,37}$ This results in inflammatory mediator production, ${ }^{38}$ relative resistance to cell death, ${ }^{36,39}$ and an increase in cell proliferation. Though the precise mechanism by which this causes liver disease has not been elucidated, it follows that abnormal cell survival in the setting of a pro-inflammatory environment may lead to both hepatitis and neoplasia.

\section{Clinical features of $\alpha_{1}$-antitrypsin deficiency related liver disease}

Intracellular polymers form inclusions that are associated with neonatal hepatitis, cirrhosis, and hepatocellular carcinoma. ${ }^{40,41}$ Cholestatic jaundice affects one in ten neonates with $\alpha_{1}$-antitrypsin deficiency, $15 \%$ of whom develop juvenile cirrhosis. Liver disease can also become clinically relevant later in life with almost $50 \%$ of patients over the age of 50 having histological features consistent with cirrhosis in an autopsy series. ${ }^{41}$ Vaccination against hepatitis $\mathrm{A}$ and $\mathrm{B}$ is recommended as viral hepatitis may predispose to development of chronic liver disease ${ }^{42}$ It is recommended that alcohol consumption does not exceed $60 \mathrm{~g}$ /day but there is currently no proven association between alcohol excess and the development of liver disease in $\alpha_{1}$-antitrypsin deficiency. ${ }^{43}$ Weight control is advisable in view of an association between obesity and cirrhosis in these individuals. ${ }^{44}$ Screening for cirrhosis and hepatocellular carcinoma (HCC) with liver ultrasound is warranted; some clinicians may choose to use serum alpha-fetoprotein as an additional screening tool for HCC. Treatment of hepatic failure follows that for any other condition; liver transplantation is an option and accounted for $1.1 \%$ of adult liver transplants in the US in the period 1995-2004. Liver transplantation cures the circulating deficiency of $\alpha_{1}$-antitrypsin and 5-year survival rates are excellent at around $83 \%{ }^{45}$

\section{Alpha-I-antitrypsin deficiency and lung disease}

Alpha-1-antitrypsin deficiency is classically associated with early-onset, lower zone emphysema. Smoking individuals with severe circulating deficiency of $\alpha_{1}$-antitrypsin tend to develop clinical disease in the third or fourth decade with the most common reported symptoms being breathlessness, cough, and wheeze. ${ }^{46}$ Those with a smoking history develop more severe disease at an earlier age than could be explained by smoking alone. There is often a significant delay from symptom onset to diagnosis ${ }^{47}$ a 2003 survey revealed a time lapse of more than 5 years between first symptom and diagnosis in a cohort of 1851 individuals with $\alpha_{1}$-antitrypsin deficiency. ${ }^{48} \mathrm{~A}$ chest radiograph typically shows hyperinflation and a paucity of vascular markings in the lower zone; pulmonary function testing reveals evidence of airflow obstruction, gas trapping, and impaired gas transfer. The natural history of $\alpha_{1}$-antitrypsin deficiency-associated emphysema is highly variable but disease is often progressive, with faster lung function decline seen in ongoing smokers, ${ }^{49}$ those with recurrent exacerbations, ${ }^{50}$ and those with environmental dust exposure. ${ }^{51}$ 
A
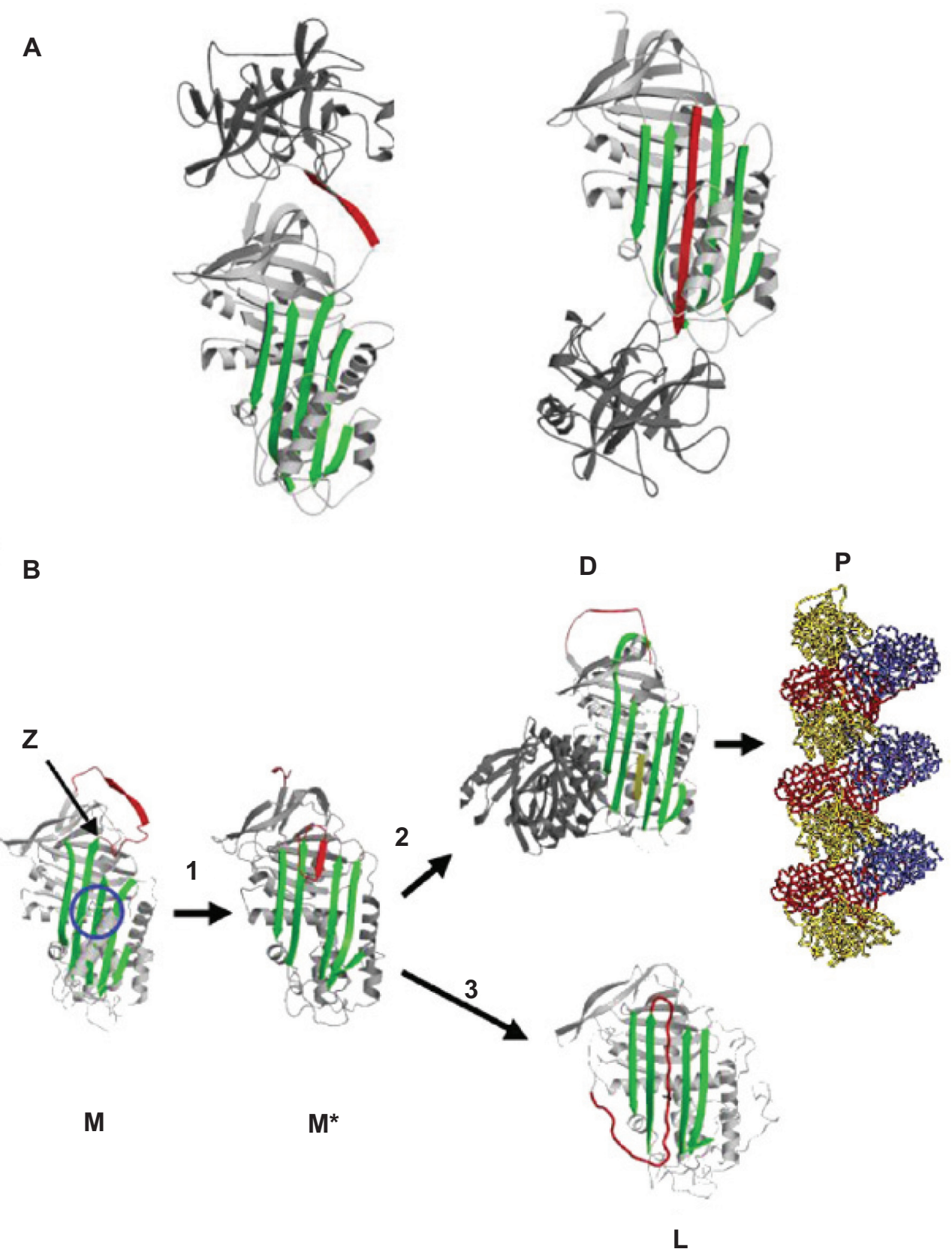

Figure I (A) Inhibition of neutrophil elastase by $\alpha_{1}$-antitrypsin. After docking (left) the neutrophil elastase (grey) is inactivated by movement from the upper to the lower pole of the protein (right). This is associated with insertion of the reactive loop (red) as an extra strand into $\beta$-sheet A (green). Reproduced from Lomas et al ${ }^{136}$ with permission. (B) The structure of $\alpha_{1}$-antitrypsin is centered on $\beta$-sheet $A$ (green) and the mobile reactive center loop (red). Polymer formation results from the $Z$ variant of $\alpha_{1}$-antitrypsin (Glu342 Lys at $\mathrm{P}_{17}$; arrowed) or mutations in the shutter domain (blue circle) that open $\beta$-sheet $\mathrm{A}$ to favor partial loop insertion (step I) and the formation of an unstable intermediate $\left(M^{*}\right)$. The patent $\beta$-sheet $A$ can either accept the loop of another molecule (step 2 ) to form a dimer (D), which then extends into polymers (P). A small proportion of the unstable serpin molecules can accept their own loop (step 3 ) to form an inactive, thermostable, latent conformation (L). The individual molecules of $\alpha_{1}$-antitrypsin within the polymer are colored red, yellow, and blue. Reproduced from Gooptu et $\mathrm{a}^{29}$ with permission.

It is apparent from the study of the rare null mutations of $\alpha_{1}$-antitrypsin that the lack of circulating protein (ie, loss-of-function) plays a vital role in the development of emphysema. Indeed, null $\alpha_{1}$-antitrypsin homozygotes have particularly severe disease. ${ }^{52}$ There is now increasing evidence that $\alpha_{1}$-antitrypsin polymers are also important in the development of the panacinar emphysema that is classically seen in this condition. Alpha-1-antitrypsin enters the lung from the circulation by passive diffusion ${ }^{53}$ and is also produced locally in alveolar macrophages and bronchial and alveolar epithelial cells. ${ }^{7,8,11}$ In individuals homozygous for the $\mathrm{Z}$ allele, all $\alpha_{1}$-antitrypsin has the propensity to form 
A

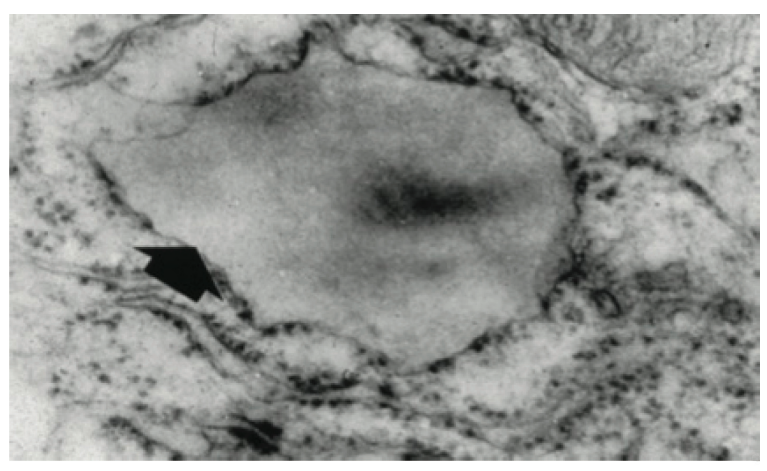

B

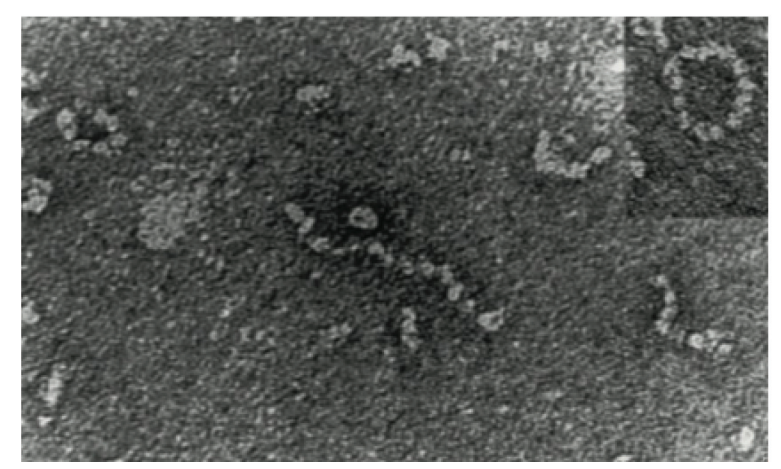

Figure 2 (A) Electron microscopy $(\times 20,000)$ of a hepatocyte from a $Z$ homozygote showing a massive inclusion (arrowed) in the endoplasmic reticulum. Reproduced from Lomas et al ${ }^{18}$ with permission. (B) The intra-hepatic polymers of mutant $Z$ $\alpha_{1}$-antitrypsin have the appearance of beads on a string on electron microscopy. Reproduced from Lomas et al ${ }^{137}$ with permission.

polymers regardless of its source. Indeed, polymers have been detected in bronchoalveolar lavage fluid ${ }^{54,55}$ and explanted lung sections from $\mathrm{Z}$ homozygotes, where they are seen both around capillaries (consistent with circulating polymers) and epithelial cells (suggesting local synthesis). This local production of polymers is exacerbated by the presence of cigarette smoke. ${ }^{56}$ The most compelling evidence for pulmonary $\alpha_{1}$-antitrypsin production of polymers comes from a bronchoalveolar lavage sample from an $\alpha_{1}$-antitrypsin ZZ homozygote following liver transplantation which contained polymers; because wildtype $M$ antitrypsin is produced from the transplanted liver this confirms that $Z \alpha_{1}$-antitrypsin is produced locally and then forms polymers. ${ }^{55}$

In stark contrast to the anti-inflammatory properties of monomeric $\mathrm{M} \alpha_{1}$-antitrypsin, $\mathrm{Z} \alpha_{1}$-antitrypsin polymers are pro-inflammatory, acting as neutrophil chemoattractants. Polymers, largely located in the interstitium, attract neutrophils as they migrate from capillary to alveolus in response to inflammatory mediators induced by cigarette smoke. ${ }^{56}$ Here they cause neutrophil degranulation and release of elastases and other degradative enzymes. ${ }^{57}$ Additionally, the lungs of $\mathrm{Z} \alpha_{1}$-antitrypsin homozygotes contain increased levels of chemotactic cytokines including interleukin-8 (IL-8) and leukotriene B4 $\left(\mathrm{LTB}_{4}\right)$, compared with controls. ${ }^{58}$ This may be a response of alveolar macrophages to uninhibited neutrophil elastase ${ }^{59}$ but may also reflect stress signaling pathways, perhaps including the UPR, induced by intracellular polymers in epithelial cells and alveolar macrophages.

The pro-inflammatory environment in the lung is further amplified by a number of other mechanisms: (i) monomeric $\mathrm{Z} \alpha_{1}$-antitrypsin is ten-fold less efficient than wild type protein at inhibiting neutrophil elastase, ${ }^{60}$ (ii) oxidation of $\alpha_{1}$-antitrypsin by superoxide radicals may not only reduce its efficacy further, ${ }^{61}$ it may also stimulate release of IL-8 and monocyte chemoattractant protein-1 from epithelial cells, ${ }^{62}$ (iii) the reduction in intracellular $\alpha_{1}$-antitrypsin may lead to loss of inhibition of caspase-3, leading to uncontrolled cellular apoptosis. ${ }^{63}$ This is in contrast to the relative paucity of apoptosis seen in the liver and perhaps reflects the activation of the UPR in response to the second hit, which is the inflammatory milieu of the lung in $Z \alpha_{1}$-antitrypsin homozygotes.

Taken together, a model for the pathogenesis of lung disease can be proposed in the $\mathrm{Z} \alpha_{1}$-antitrypsin homozygote involving both loss-of-function and gain-of-function components. The lack of functional $\alpha_{1}$-antitrypsin (due to reduced secretion, reduced antiprotease activity, and the polymerization of $Z \alpha_{1}$-antitrypsin) creates a pro-inflammatory and proteolytic environment. This is exacerbated by the presence of interstitial polymers and cytokines, both of which are chemotactic for neutrophils, and can be further driven by oxidation of $\alpha_{1}$-antitrypsin due to cigarette smoke. Finally, a lack of intracellular $\alpha_{1}$-antitrypsin prevents inhibition of apoptotic pathways. The resulting inflammation, proteolysis, and cell death lead to the development of panacinar emphysema, the hallmark of $\alpha_{1}$-antitrypsin deficiency-related lung disease.

\section{Systemic diseases associated with $\alpha_{1}$-antitrypsin deficiency}

Alpha-1-antitrypsin deficiency is associated with other inflammatory conditions including panniculitis and anti-neutrophil cytoplasmic antibody (ANCA) positive vasculitis. The lesions of panniculitis contain neutrophils that co-localize with polymers, though normal skin of the $\mathrm{Z} \alpha_{1}$-antitrypsin homozygote also contains polymers. ${ }^{31}$ It remains to be seen whether polymers are simply an incidental finding, or whether they play a role in the pathogenesis of the disease. The repeated observation that intravenous 
$\alpha_{1}$-antitrypsin replacement therapy can have an effect on flare frequency and severity of panniculitis ${ }^{64}$ points to loss-offunction being of greater significance in this manifestation of disease.

Case-control studies have confirmed a link between $\mathrm{Z}$ $\alpha_{1}$-antitrypsin deficiency and ANCA-associated vasculitis, and polymers can also be seen in the renal biopsies of affected individuals. ${ }^{32}$ In addition to the low absolute levels of circulating $\alpha_{1}$-antitrypsin, it is postulated that polymers may become trapped within glomeruli, promoting neutrophil degranulation and inflammation as they do within the interstitium of the lung. ${ }^{32}$

\section{Current treatment strategies}

The management of patients with $\alpha_{1}$-antitrypsin deficiency related emphysema closely resembles that of patients with "usual" smoking related COPD. Smoking cessation is crucial to prevent progression of disease with the rate of forced expiratory volume in 1 second $\left(\mathrm{FEV}_{1}\right)$ decline being significantly less in those who quit successfully. ${ }^{49}$ Other potentially preventative strategies include minimization of respiratory irritant exposure and pneumococcal and influenza vaccination ${ }^{43}$ Inhaled corticosteroids are commonly used and theoretically should reduce neutrophilic airway inflammation; small studies have suggested a possible benefit in terms of lung function in some patients ${ }^{65,66}$ and inhaled bronchodilators may result in symptomatic benefit despite little objective evidence of a bronchodilator response. Oxygen used in accordance with national guidelines and pulmonary rehabilitation programs may also be useful.

Lung volume reduction surgery (LVRS) is uncommonly used in individuals with $\alpha_{1}$-antitrypsin deficiency. Individuals with emphysema of any cause with predominantly basal disease have a worse outcome than those with upper lobe disease ${ }^{67}$ Alpha-1-antitrypsin deficient patients undergoing LVRS achieve initial improvements in $\mathrm{FEV}_{1}$ and exercise tolerance comparable with non-deficient patients but the benefits are shorter lived. ${ }^{68}$ It has been suggested that this is a consequence of disease distribution rather than $\alpha_{1}$-antitrypsin deficiency per $\mathrm{se}^{68}$ but currently the American Thoracic Society/European Respiratory Society guidelines do not recommend this procedure pending the emergence of further evidence..$^{43}$ There are case reports of successful use of less invasive procedures including endobronchial valve placement ${ }^{69}$ though experience remains limited.

Lung transplantation is also an option for patients with end-stage emphysema. Because COPD often develops at an early age in $\alpha_{1}$-antitrypsin-deficient individuals, they tend to be good candidates. Alpha-1-antitrypsin deficiency accounted for $3.2 \%$ of lung transplants (and 10\% of transplants for emphysema) in the International Society for Heart and Lung Transplantation Registry in $2009,{ }^{70}$ with a 1-year survival rate of $86 \%$ and a 3-year survival of $69 \%$ for transplants performed between 2006-2010. These figures are comparable with the general COPD population, $84 \%$ of whom are alive at 1 year and $67 \%$ at 3 years posttransplant.

\section{Alpha-I antitrypsin replacement therapy: current practice}

The concept of using purified human $\alpha_{1}$-antitrypsin as intravenous replacement therapy was first described in 1981 by Gadek and colleagues who demonstrated normalization of serum $\alpha_{1}$-antitrypsin levels and establishment of anti-elastase activity within the lower respiratory tract with weekly infusions. ${ }^{21}$ Alpha-1 antitrypsin replacement therapy was subsequently approved by the United States Food and Drug Administration (FDA) in 1987 based on the demonstration that normal serum levels could be achieved with regular treatment. ${ }^{71}$ It is also available in Canada and many European countries and replacement therapy is recommended in the joint American Thoracic Society/European Thoracic Society statement on the management of $\alpha_{1}$-antitrypsin deficiency. ${ }^{43}$ Many other countries including the UK, New Zealand, and Australia await proof of clinical benefit before licensing. It is not indicated in individuals who have partial $\alpha_{1}$-antitrypsin deficiency (MZ heterozygotes) and in $\alpha_{1}$-antitrypsin deficiency-associated liver disease.

Replacement therapy is given as weekly intravenous infusions at a dose of $60 \mathrm{mg} / \mathrm{kg}$. This is based on evidence that with such dosing, trough $\alpha_{1}$-antitrypsin levels can be kept above the "protective" threshold of $80 \mathrm{mg} / \mathrm{dL}$. This threshold is based on the observation that patients with heterozygous phenotypes whose levels of $\alpha_{1}$-antitrypsin exceed this level do not usually develop lung disease. ${ }^{71}$ Four options are available for replacement therapy in the US: Prolastin ${ }^{\circledR}$ (Talecris Biotherapeutics, Research Triangle Park, NC), Aralast ${ }^{\circledR}$ (Baxter Healthcare, Deerfield, IL), Zemaira ${ }^{\circledR}$ (CSL Behring, King of Prussia, PA), and Glassia ${ }^{\circledR}$ (Baxter, Deerfield, IL), with a fifth, Trypsone ${ }^{\circledR}$ (Grifols, Barcelona, Spain), available in Spain. All consist of purified human $\alpha_{1}$-antitrypsin. The individual characteristics of each have been thoroughly reviewed elsewhere ${ }^{72}$ but they all appear to be equally effective with subtle differences in storage, preparation, infusion rate, and cost. Glassia ${ }^{\circledR}$, licensed in October 2009 by the FDA, is the only ready-to-use formulation but requires a slower infusion rate of $0.04 \mathrm{~mL} / \mathrm{kg} /$ minute, half that of the other preparations. The cost of replacement is dependent on body 
mass but may be upwards of US $\$ 100,000$ per annum - and is a lifelong treatment. ${ }^{73}$

Intravenous $\alpha_{1}$-antitrypsin is generally considered to be well tolerated and safe. It is contraindicated in patients with IgA deficiency as purified protein may contain small amounts of $\operatorname{IgA}$, prompting a severe hypersensitivity reaction. As it is purified from human plasma there is a theoretical risk of transmission of infectious agents including viruses and prions, but such transmission has never been reported. The commonest reported side effects from the original preparation $\left(\right.$ Prolastin $^{\circledR}$ ) are dizziness, fainting, and dyspnea. ${ }^{74}$

\section{Alpha-I-antitrypsin replacement therapy: evidence of efficacy}

Evidence of a biochemical effect of weekly intravenous antitrypsin was quick to emerge. Serum $\alpha_{1}$-antitrypsin levels can be maintained above the postulated protective level and anti-elastase activity can concurrently be detected in bronchoalveolar lavage fluid. ${ }^{71}$ Infused $\alpha_{1}$-antitrypsin is functionally active and antibodies do not develop following repeated infusion. ${ }^{75}$ There are inherent difficulties in attempting to establish the clinical efficacy of $\alpha_{1}$-antitrypsin replacement therapy. Though the gene frequency makes $\alpha_{1}$-antitrypsin deficiency as common as cystic fibrosis, the heterogeneous nature of the disease means that only around $5 \%-10 \%$ of patients have been diagnosed..$^{76}$ This means that the pool of patients on whom to undertake trials is relatively small and inevitably results in the majority of evidence coming from larger observational studies rather than the few randomized controlled trials, each of which contains a small number of participants. ${ }^{77}$ Additionally, the evolution of emphysema is slow, meaning that protracted studies are necessary to show differences in lung function decline and mortality. ${ }^{78}$ Indeed, Schluchter et al estimated that to detect a $40 \%$ reduction in mortality in 5 years, 684 $\alpha_{1}$-antitrypsin deficient individuals with an $\mathrm{FEV}_{1}$ of $35 \%-49 \%$ predicted would need to be recruited over a 2-year period. ${ }^{79}$ Furthermore enthusiasm from pharmaceutical companies to fund such trials may be lacking with their products already freely available in many countries.

\section{Non-randomized trials}

It was not until 1997 that the first observational study with concurrent controls addressing clinical efficacy of $\alpha_{1}$-antitrypsin replacement therapy was published. Seersholm and colleagues demonstrated a significantly slower rate of $\mathrm{FEV}_{1}$ decline in a cohort of 198 German $\alpha_{1}$-antitrypsin deficient patients on replacement therapy when compared with 97 Danish controls, particularly in those with an $\mathrm{FEV}_{1}$ of $31 \%-65 \%$ predicted.$^{80}$ In 1998 the National Heart Lung and Blood Institute $\alpha_{1}$-antitrypsin deficiency registry study group reported on 927 patients enrolled in their registry. They showed no overall difference in lung function decline between treated and untreated groups. However there was a significant benefit of treatment seen in those with moderate impairment of lung function $\left(\mathrm{FEV}_{1} 30 \%-64 \%\right.$ predicted); conversely those with an $\mathrm{FEV}_{1}>80 \%$ predicted had a faster annual decline in $\mathrm{FEV}_{1}$ whilst on treatment than untreated individuals $(P=0.09)$. They also reported overall mortality figures in favor of $\alpha_{1}$-antitrypsin replacement, though no difference in those with an $\mathrm{FEV}_{1}>50 \%$ predicted. ${ }^{81}$ Wencker et al took a different approach in 2001, comparing decline in lung function in 96 patients before and after initiation of augmentation therapy. These authors observed an overall benefit of treatment, but in contrast to previous observational studies, they demonstrated no significant difference in those with $\mathrm{FEV}_{1}$ in the range $30 \%-65 \%$. The most significant benefit was seen in the small subgroup with mildly impaired ( $>65 \%$ predicted at enrolment) but rapidly declining $\mathrm{FEV}_{1}$, with annual $\mathrm{FEV}_{1}$ loss reducing from $255.7 \mathrm{~mL} /$ year to $45.8 \mathrm{~mL} /$ year on augmentation therapy $(P=0.0016) .{ }^{82}$ Recently Tonelli et al studied 164 individuals from the Alpha-1 Foundation DNA and Tissue Bank, finding a benefit of treatment in ex-smokers with an $\mathrm{FEV}_{1}$ of less than $50 \%$ predicted. It was again noted that those with better lung function $\left(\mathrm{FEV}_{1}>60 \%\right.$ predicted $)$ did worse on augmentation therapy as measured by $\mathrm{FEV}_{1}$ decline. ${ }^{83}$ This finding may in part be explained by a tendency for those with good but rapidly declining lung function to be started on augmentation therapy. The authors of these observational studies all acknowledge the limitations of their findings. Treatment decisions were made by patients' physicians and the baseline demographics between groups were unmatched; in particular the baseline $\mathrm{FEV}_{1}$ was lower in the treatment cohort in all studies.

\section{Randomized controlled trials}

Alpha-1-antitrypsin replacement therapy had been available in the United States for 12 years before the first of two randomized controlled trials (RCTs) assessing its efficacy was published. In 1999 Dirksen et $\mathrm{al}^{84}$ reported on a cohort of 58 ex-smokers with severe plasma $\alpha_{1}$-antitrypsin deficiency and an $\mathrm{FEV}_{1}$ of $30 \%-80 \%$ predicted. The active group was treated with $250 \mathrm{mg} / \mathrm{kg}$ iv $\alpha_{1}$-antitrypsin at 4-weekly intervals for at least 3 years. This dose had previously been shown to provide protective serum $\alpha_{1}$-antitrypsin levels for an average of 25 days of the 28-day interval. ${ }^{85}$ The study's primary outcome measure was $\mathrm{FEV}_{1}$; there was no statistically 
significant difference between groups but a trend toward faster decline of $\mathrm{FEV}_{1}$ was seen in the treated group. In contrast the authors were able to demonstrate a trend towards slower loss of lung density (measured by computed tomography [CT]) in the treated group, albeit with substantial deterioration in both groups. The study was not designed to address mortality.

In 2009 the results of the "exacerbations and computed tomography scan as lung end-points" (EXACTLE trial), ${ }^{86}$ which used CT-assessed lung density as its primary outcome measure, were published. Participants had severe $\alpha_{1}$-antitrypsin deficiency, were ex- or never smokers and members of the treatment group were given $60 \mathrm{mg} / \mathrm{kg}$ weekly iv $\alpha_{1}$-antitrypsin replacement (the accepted dosing regimen) for a minimum of 2 years. The authors again reported loss of lung density in both groups with a difference of borderline significance in favor of the treatment group over the entire treatment period in one of four analysis methods. No difference was seen in lung function parameters or exacerbation rate between groups, though a post hoc analysis suggested that exacerbation severity may be milder in the treatment group. A third RCT which plans to address the question of mortality, albeit only as a secondary endpoint, is ongoing. ${ }^{87}$

A meta-analysis of some of the early trials comprising 1509 patients concluded that $\mathrm{FEV}_{1}$ decline was slower in treated versus untreated individuals. ${ }^{80-82,84,88}$ This was particularly evident in those with an $\mathrm{FEV}_{1}$ of $30 \%-65 \%$ predicted, who experienced a $26 \%$ reduction in the rate of decline in $\mathrm{FEV}_{1}$ as a result of replacement therapy. ${ }^{89}$ The randomized trials were the subject of two meta-analyses that reached quite different conclusions. A Cochrane review concluded that a lack of evidence regarding mortality combined with conflicting evidence for treatment efficacy from $\mathrm{FEV}_{1}$ and $\mathrm{CT}$ data meant that replacement therapy cannot be recommended at present and that further studies should be large enough to detect an effect on mortality. ${ }^{22} \mathrm{~A}$ response from the expert community raised concerns over the methodology of this review, particularly regarding differences in drug and dosing regimens, and dropout rates between studies. The authors also questioned whether observational data should have been included in a meta-analysis of this rare condition. ${ }^{77}$

Stockley and colleagues re-analyzed the 1999 RCT data and, combined with the EXACTLE data, demonstrated a significant reduction in lung density decline in the treated versus untreated group $(P=0.006)$. They agreed that further studies are warranted, but that there is sufficient evidence of treatment efficacy that in future trials an iv placebo group is not ethically warranted. ${ }^{90}$

\section{Exacerbations and airway inflammation}

One study asking patients to self-report symptoms after initiation of replacement therapy found that 56 of 89 patients reported a definite decrease in exacerbation number from an average of $3-5$ per year to $0-1$ per year. ${ }^{91}$ Others have noted ongoing exacerbations despite treatment ${ }^{92}$ and the EXACTLE trial did not find a reduction in exacerbation frequency on treatment. Augmentation therapy does however seem to have an effect upon markers of airway inflammation. Stockley et al noted an increase in sputum $\alpha_{1}$-antitrypsin to the levels seen in nondeficient individuals with intravenous replacement; this was associated with a decrease in sputum $\mathrm{LTB}_{4}$ but there was no significant change in markers of neutrophil number and activation: IL-8 and myeloperoxidase (MPO). They suggest that this may reflect decreased $\mathrm{LTB}_{4}$ secretion by macrophages due to a reduction in uninhibited elastase..$^{93}$

Table 2 summarizes the trial data discussed above. The very nature of observational studies along with their conflicting results must limit their role in confirming treatment efficacy. RCTs to date have been small scale. They suggest a lack of treatment benefit as measured by lung function, but raise the possibility of a positive impact on the rate of lung density loss as measured by CT, a parameter thought to be a more accurate measure of disease progression than lung function. ${ }^{94}$ The effect of augmentation therapy on mortality has not been adequately addressed. As outlined by Schluchter and colleagues ${ }^{79}$ the scale of trial required would be likely to require international collaboration. With disparate current clinical practice and a lack of agreement on the ethical design of future trials to assess disease progression, it seems this question will remain unanswered.

\section{Assessing replacement therapy in the context of disease pathogenesis}

Practical problems with clinical assessment of intravenous $\alpha_{1}$-antitrypsin replacement have been outlined above. Putting this treatment in the context of disease pathogenesis may provide more understanding of the questionable efficacy demonstrated to date. Weekly iv $\alpha_{1}$-antitrypsin provides protective levels of circulating protein as measured by a threshold over which individuals do not develop lung disease. However $\alpha_{1}$-antitrypsin is an acute phase protein with levels increasing by up to $130 \%$ in response to stress and peaking at up to $6 \mathrm{~g} / \mathrm{L} ;{ }^{95}$ perhaps the ability to mount such a response may be of critical importance rather than the baseline level. Alpha-1-antitrypsin secretion may also be under the control of growth hormone working synergistically with other pituitary hormones, which leads to variable hepatic serum 
Table 2 Studies of $\alpha_{1}$-antitrypsin replacement therapy

\begin{tabular}{|c|c|c|c|}
\hline Author(s) & Study type & $\begin{array}{l}\text { Primary (secondary) } \\
\text { outcome measure(s) }\end{array}$ & Salient results \\
\hline \multicolumn{4}{|c|}{ Non-randomized studies } \\
\hline Seersholm et al ${ }^{80}$ & $\begin{array}{l}\text { Observational study with } \\
\text { concurrent controls }\end{array}$ & FEV , decline & $\begin{array}{l}\text { - Slower FEV, decline in treated group } \\
\text { Most marked benefit in those with } \mathrm{FEV}, 31 \%-65 \% \\
\text { predicted }\end{array}$ \\
\hline NHLBI study ${ }^{81}$ & $\begin{array}{l}\text { Observational study with } \\
\text { concurrent controls }\end{array}$ & $\begin{array}{l}\text { FEV, decline; } \\
\text { Mortality }\end{array}$ & $\begin{array}{l}\text { - No overall difference in } \mathrm{FEV} \text {, decline } \\
\text { Slower FEV, decline in those with } \mathrm{FEV}, 30 \%-64 \% \text { predicted } \\
\text { Faster decline in those with } \mathrm{FEV}_{1}>75 \% \text { predicted } \\
\text { - Decreased mortality in treated group }\end{array}$ \\
\hline Wencker et al ${ }^{82}$ & $\begin{array}{l}\text { Observational study of patients } \\
\text { pre- and during treatment }\end{array}$ & FEV, decline & $\begin{array}{l}\text { - Overall slower FEV, decline on treatment } \\
\text { Most significant benefit in those with } \mathrm{FEV},>65 \% \\
\text { no significant difference in those with } \mathrm{FEV}, 30 \%-65 \%\end{array}$ \\
\hline Tonelli et al ${ }^{83}$ & $\begin{array}{l}\text { Observational study with } \\
\text { concurrent controls }\end{array}$ & $\begin{array}{l}\text { FEV, decline } \\
\text { (mortality) }\end{array}$ & $\begin{array}{l}\text { - Slower decline in treated group if } \mathrm{FEV}_{1}<50 \% \text { predicted and } \\
\text { ex-smoker. } \\
\text { Faster decline in treated group if } \mathrm{FEV}_{1}>60 \% \text {. } \\
\text { - No difference in mortality }\end{array}$ \\
\hline \multicolumn{4}{|l|}{ RCTs } \\
\hline Dirksen et $\mathrm{a}^{84}$ & $\begin{array}{l}\text { Double-blind placebo } \\
\text { controlled RCT }\end{array}$ & $\begin{array}{l}\mathrm{FEV}_{1} / \mathrm{D}_{\mathrm{LCO}} \text { decline, } \\
\text { (CT densitometry) }\end{array}$ & $\begin{array}{l}\text { - No difference in } F E V_{1} \text { or } D_{L C O} \\
\text { - Trend towards slower annual loss of lung density in treated } \\
\text { group }\end{array}$ \\
\hline Dirksen et $\mathrm{al}^{86}$ & $\begin{array}{l}\text { Double-blind placebo } \\
\text { controlled RCT }\end{array}$ & $\begin{array}{l}\text { CT densitometry } \\
\text { (lung function, } \\
\text { health status, exacerbations) }\end{array}$ & $\begin{array}{l}\text { - Trend towards reduction in lung density loss in treated group } \\
\text { - No difference in } F E V_{1} \text { or } D_{L C O} \\
\text { - No difference in exacerbation rate but exacerbations less } \\
\text { severe in treated group }\end{array}$ \\
\hline \multicolumn{4}{|l|}{ Meta-analyses } \\
\hline $\begin{array}{l}\text { Gøtzsche and } \\
\text { Johansen }{ }^{22}\end{array}$ & Review of RCTs & $\begin{array}{l}\text { Mortality, } \\
\text { FEV, decline }\end{array}$ & $\begin{array}{l}\text { - Reduction in lung density loss in treated group over whole } \\
\text { trial period } \\
\text { - Trend towards faster FEV, decline in treated group }(P=0.06)\end{array}$ \\
\hline Stockley et $\mathrm{al}^{90}$ & Integrated analysis of RCTs & $\begin{array}{l}\text { CT densitometry, } \\
\text { FEV, decline }\end{array}$ & $\begin{array}{l}\text { - Reduction in lung density loss in treated group }(P=0.006) \\
\text { - Trend towards faster FEV, decline in treated group }(P=0.32 \mathrm{I})\end{array}$ \\
\hline \multicolumn{4}{|c|}{ Studies on exacerbations } \\
\hline Lieberman $^{91}$ & Patient survey & $\begin{array}{l}\text { Exacerbation } \\
\text { frequency }\end{array}$ & $\begin{array}{l}\text { - Reduction in exacerbation frequency from } 3-5 \text { per annum } \\
\text { to } 0-1 \text { per annum following initiation of treatment }\end{array}$ \\
\hline Stockley et $\mathrm{al}^{93}$ & $\begin{array}{l}\text { Clinical study using BAL } \\
\text { from patients on } \alpha_{1} \text {-antitrypsin } \\
\text { replacement }\end{array}$ & $\begin{array}{l}\text { Sputum inflammatory } \\
\text { markers }\end{array}$ & $\begin{array}{l}\text { - Sputum } \mathrm{LTB}_{4} \text { significantly reduced following weekly } \\
60 \mathrm{mg} / \mathrm{kg} \alpha_{1} \text {-antitrypsin replacement. } \\
\text { - Non-significant reductions in IL-8 and MPO }\end{array}$ \\
\hline
\end{tabular}

Abbreviations: $B A L$, bronchoalveolar lavage fluid; $D_{L C O}$ diffusing capacity of the lung for carbon monoxide; $C T$, computed tomography; FEV forced expiratory volume in I second; IL-8, interleukin 8; $\mathrm{LTB}_{4}$, leukotriene B4; MPO, myeloperoxidase; NHLBI, national heart lung and blood institute; RCTs, randomized controlled trials.

and mRNA levels. ${ }^{96}$ Replacement therapy cannot address this; it can be envisaged that a patient would be particularly vulnerable shortly before the next infusion is due, especially the significant number of individuals who receive bi-weekly or monthly treatment. ${ }^{81}$ Based on knowledge of disease pathogenesis it follows that $\alpha_{1}$-antitrypsin replacement therapy should address some of the drivers of lung disease: (i) it can effectively inhibit neutrophil elastase where the inefficient $\mathrm{Z} \alpha_{1}$-antitrypsin monomers and inactive polymers would otherwise leave uninhibited elastase activity; (ii) the resulting lack of free elastase reduces $\mathrm{LTB}_{4}$ release from alveolar macrophages, thereby reducing the chemotactic signaling to neutrophils. ${ }^{93}$ Despite this, levels of MPO are unchanged in those on replacement suggesting that equal numbers of neutrophils are present (though they will have their elastase inhibited).

However replacement therapy will not affect (i) the formation of $Z \alpha_{1}$-antitrypsin polymers that become lodged in the lung interstitium and act as neutrophil chemoattractants; (ii) intracellular $Z \alpha_{1}$-antitrypsin polymers in epithelial cells and alveolar macrophages that continue to induce stress signaling and release of pro-inflammatory cytokines.

We can postulate that a patient on augmentation therapy may have less tissue destruction as a result of better regulation of neutrophil elastase activity, but will continue to have chronic inflammation in response to intrapulmonary polymers. In the small minority of patients who are $\alpha_{1}$-antitrypsin ${ }_{\text {null }}$ homozygotes then lung damage entirely reflects the absence 
of neutrophil elastase inhibition. This group is most likely to benefit from replacement therapy. However in the majority of patients who have polymerogenic mutations it may be that the benefit of replacement therapy is attenuated by the ongoing inflammatory response to polymers.

Clinical and laboratory studies designed specifically to address this question would be of enormous value. A trial comparing treatment efficacy in individuals homozygous for null $\alpha_{1}$-antitrypsin alleles with those with polymerogenic alleles may shed light on the impact of $\alpha_{1}$-antitrypsin polymers in attenuating the beneficial effects of augmentation therapy. This would provide crucial information on the relative role of $\alpha_{1}$-antitrypsin polymers in the pathogenesis of emphysema. Additionally if small molecules that block $\alpha_{1}$-antitrypsin polymerization ${ }^{97}$ can be further developed, these can be tested in vivo to determine whether the absence of intrapulmonary polymers slows the rate of development of emphysema.

\section{Conclusion}

The current literature provides good evidence of the safety and biochemical effect of intravenous $\alpha_{1}$-antitrypsin replacement but there is no widely accepted proof that it affects disease progression or mortality. Further large scale RCTs would help clarify the impact of long-term intravenous $\alpha_{1}$-antitrypsin replacement on loss of lung density, which is emerging as an important surrogate marker of disease. Combined results from such trials may confirm CT densitometry as the best marker of disease severity and progression in $\alpha_{1}$-antitrypsin deficiency as well as adding to a body of evidence that could be used to determine any effect on mortality.

The evolving knowledge of the molecular basis of disease requires us to re-evaluate the utility of replacement therapy in individuals with $\alpha_{1}$-antitrypsin deficiency. A logical approach is to turn away from simply replacing deficient protein and toward tackling the key feature of this disease: the tendency of mutant $\alpha_{1}$-antitrypsin to polymerize. ${ }^{18}$ Strategies that result in the secretion of normally folded, functional protein would impact on both intracellular stress signaling and the systemic inflammation caused by polymers and in turn should prevent the development of both liver and lung disease, although whether this will become a reality remains to be seen.

\section{Acknowledgments}

JAD is an MRC Clinical Training Fellow. DAL is supported by the Medical Research Council (UK), the Engineering and Physical Sciences Research Council, GlaxoSmithKline, the Alpha-1 Foundation, and Papworth NHS Trust.

\section{Disclosure}

The authors report no conflicts of interest in this work.

\section{References}

1. Laurell C-B, Eriksson S. The electrophoretic $\alpha_{1}$-globulin pattern of serum in $\alpha_{1}$-antitrypsin deficiency. Scand J Clin Lab Invest. 1963;15: 132-140.

2. Sharp HL, Bridges RA, Krivit W, Freier EF. Cirrhosis associated with alpha-1-antitrypsin deficiency: a previously unrecognized inherited disorder. J Lab Clin Med. 1969;73(6):934-939.

3. King MA, Stone JA, Diaz PT, et al. $\alpha_{1}$-antitrypsin deficiency: evaluation of bronchiectasis with CT. Radiology. 1996;199(1):137-141.

4. Eden E, Mitchell D, Mehlman B, et al. Atopy, asthma, and emphysema in patients with severe alpha-1-antitrypsin deficiency. Am J Respir Crit Care Med. 1997;156(1):68-74.

5. Griffith ME, Lovegrove JU, Gaskin G, Whitehouse DB, Pusey CD. $\mathrm{C}$-antineutrophil cytoplasmic antibody positivity in vasculitis patients is associated with the $\mathrm{Z}$ allele of alpha-1-antitrypsin, and the P-antineutrophil cytoplasmic antibody positivity with the S allele. Nephrol Dial Transplant. 1996;11(3):438-443.

6. Bleumink E, Klokke AH. Relationship between Weber-Christian panniculitis and the ZZ phenotype of alpha ${ }_{1}$-antitrypsin. Arch Dermatol Res. 1985;277(4):328-329.

7. Cichy J, Potempa J, Travis J. Biosynthesis of $\alpha 1$-proteinase inhibitor by human-derived epithelial cells. J Biol Chem. 1997;272(13): 8250-8255.

8. Venembre P, Boutten A, Seta N, et al. Secretion of alpha 1-antitrypsin by alveolar epithelial cells. FEBS Lett. 1994;346(2-3):171-174.

9. Geboes K, Ray MB, Rutgeerts P, Callea F, Desmet VJ, Vantrappen G. Morphological identification of alpha-1-antitrypsin in the human small intestine. Histopathology. 1982;6(1):55-60.

10. Paakko P, Kirby M, du Bois RM Gillissen A, Ferrans VJ, Crystal RG. Activated neutrophils secrete stored alpha-1 antitrypsin. Am J Respir Crit Care Med. 1996;154(6 pt 1):1829-1833.

11. Cohen $\mathrm{AB}$. Interrelationships between the human alveolar macrophage and alpha-1-antitrypsin. J Clin Invest. 1973;52(11):2793-2799.

12. Cox DW, Woo SL, Mansfield T. DNA restriction fragments associated with alpha 1-antitrypsin indicate a single origin for the deficiency allele PI Z. Nature. 1985;316(6023):79-81.

13. Blanco I, de Serres FJ, Fernández-Bustillo E, Lara B, Miravitlles M. Estimated numbers and prevalence of PI*S and PI*Z alleles of $\alpha_{1}$-antitrypsin deficiency in European countries. Eur Respir J. 2006; 27(1):77-84.

14. de Serres FJ. Worldwide racial and ethnic distribution of alpha1antitrypsin deficiency: summary of an analysis of published genetic epidemiologic surveys. Chest. 2002;122(5);1818-1829.

15. Seyama K, Nukiwa T, Souma S, Shimizu K, Kira S. Alpha 1-antitrypsindeficient variant Siiyama (Ser53[TCC] to Phe53[TTC]) is prevalent in Japan. Status of alpha 1-antitrypsin deficiency in Japan. Am J Respir Crit Care Med. 1995;152(6 pt 1):2119-2126.

16. Ferrarotti I, Baccheschi J, Zorzetto M, Tinelli C, Corda L, Balbi B, et al. Prevalence and phenotype of subjects carrying rare variants in the Italian registry for alpha1-antitrypsin deficiency. J Med Genet. 2005; 42(3):282-287.

17. Lee JH, Brantly M. Molecular mechanisms of alpha1-antitrypsin null alleles. Respir Med. 2000;94(Suppl C):S7-S11.

18. Lomas DA, Evans DL, Finch JT, Carrell RW. The mechanism of Z $\alpha_{1}$-antitrypsin accumulation in the liver. Nature. 1992;357(6379): 605-607.

19. Larsson C. Natural history and life expectancy in severe alpha1antitrypsin deficiency, PiZ. Acta Med Scand. 1798;204(5):345-351.

20. Lieberman J, Winter B, Sastre A. Alpha 1-antitrypsin Pi-types in 965 COPD patients. Chest. 1986;89(3):370-373.

21. Gadek JE, Klein HG, Holland, PV, Crystal RG. Replacement therapy of alpha 1-antitrypsin deficiency. Reversal of protease-antiprotease imbalance within the alveolar structures of PiZ subjects. J Clin Invest. 1981;68(5):1158-1165. 
22. Gøtzsche PC, Johansen HK. Intravenous alpha-1 antitrypsin augmentation therapy for treating patients with alpha-1 antitrypsin deficiency and lung disease. Cochrane Database Syst Rev. 2010;7: CD007851.

23. Yu M-H, Lee KN, Kim J. The Z type variation of human $\alpha_{1}$-antitrypsin causes a protein folding defect. Nat Struct Biol. 1995;2(5):363-367.

24. Kang HA, Lee KN, Yu MH. Folding and stability of the $Z$ and Siiyama genetic variants of human $\alpha_{1}$-antitrypsin. J Biol Chem. 1997;272(1): 510-516.

25. Wu Y, Swulius MT, Moremen KW, Sifers RN. Elucidation of the molecular logic by which misfolded $\alpha 1$-antitrypsin is preferentially selected for degradation. Proc Natl Acad Sci U S A. 2003;100(14): 8229-8234.

26. Kroeger H, Miranda E, MacLeod I, et al. Endoplasmic reticulumassociated degradation (ERAD) and autophagy cooperate to degrade polymerogenic mutant serpins. J Biol Chem. 2009;284(34): 22793-22802.

27. Qu D, Teckman JH, Omura S, Perlmutter DH. Degradation of a mutant secretory protein, $\alpha 1$-antitrypsin $Z$, in the endoplasmic reticulum requires proteasome activity. J Biol Chem. 1996;271(37):22791-22795.

28. Le A, Ferrell GA, Dishon DS, Le QQ, Sifer RN. Soluble aggregates of the human PiZ á -antitrypsin variant are degraded within the endoplasmic reticulum by a mechanism sensitive to inhibitors of protein synthesis. J Biol Chem. 1992;267(2):1072-1080.

29. Gooptu B, Hazes B, Chang WS, et al. Inactive conformation of the serpin alpha(1)-antichymotrypsin indicates two-stage insertion of the reactive loop: implications for inhibitory function and conformational disease. Proc Natl Acad Sci U S A. 2000;97(1):67-72.

30. Mahadeva R, Atkinson $\mathrm{C}$, Li Z, et al. Polymers of $Z \alpha_{1}$-antitrypsin co-localize with neutrophils in emphysematous alveoli and are chemotactic in vivo. Am J Path. 2005;166(2):377-386.

31. Gross B, Grebe M, Wencker M, Stoller JK, Bjursten LM, Janciauskiene S. New findings in PiZZ alpha1-antitrypsin deficiency-related panniculitis. Demonstration of skin polymers and high dosing requirements of intravenous augmentation therapy. Dermatology. 2009;218(4):370-375.

32. Morris H, Morgan MD, Woods A, et al. ANCA-associated vasculitis is linked to carriage of the $\mathrm{Z}$ allele of $\alpha_{1}$-antitrypsin and its polymers. Ann Rheum Dis. 2011. In press.

33. Ron D, Walter P. Signal integration in the endoplasmic reticulum unfolded protein response. Nat Rev Mol Cell Biol. 2007;8(7):519-529.

34. Pahl HL, Sester M, Burgert HG, Baeuerle PA. Activation of transcription factor NF-kappaB by the adenvirus E3/19 K protein requires its ER retention. J Cell Biol. 1996;132(4):511-522.

35. Graham KS, Le A, Sifers RN. Accumulation of the insoluble PiZ variant of human $\alpha 1$-antitrypsin within the hepatic endoplasmic reticulum does not elevate the steady-state level of grp78/BiP. J Biol Chem. 1990; 265(33):20463-20468.

36. Hidvegi T, Schmidt BZ, Hale P, Perlmutter DH. Accumulation of mutant $\alpha 1$-antitrypsin $\mathrm{Z}$ in the endoplasmic reticulum activates caspases -4 and $-12, \mathrm{NF}-\kappa \mathrm{B}$, and BAP31 but not the unfolded protein response. J Biol Chem. 2005;280(47):39002-39015.

37. Davies MJ, Miranda E, Roussel BD, Kaufman RJ, Marciniak SJ, Lomas DA. Neuroserpin polymers activate NF-kappaB by a calcium signalling pathway that is independent of the unfolded protein response. J Biol Chem. 2009;284(27):18202-18209.

38. Lawless MW, Greene CM, Mulgrew A, Taggart CC, O’Neill SJ, McElvaney NG. Activation of endoplasmic reticulum-specific stress responses associated with the conformational disease $\mathrm{Z} \alpha 1$-antitrypsin deficiency. J Immunol. 2004;172(9):5722-5726.

39. Rudnick DA, Liao Y, An JK, Muglia LJ, Perlmutter DH, Teckman JH. Analyses of hepatocellular proliferation in a mouse model of $\alpha-1$ antitrypsin deficiency. Hepatology. 2004;39(4):1048-1055.

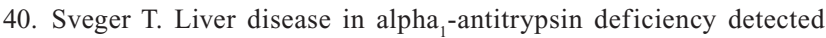
by screening of 200,000 infants. $N$ Engl J Med. 1976;294(24): 1316-1321.

41. Eriksson S, Carlson J, Velez R. Risk of cirrhosis and primary liver cancer in alpha ${ }_{1}$-antitrypsin deficiency. $N$ Engl J Med. 1986;314(12): 736-739.
42. Hashemi M, Alavian SM, Ghavami S, et al. High prevalence of alpha 1 antitrypsin phenotypes in viral hepatitis B infected patients in Iran. Hepatol Res. 2005;33(4):292-297.

43. American Thoracic Society, European Respiratory Society. American Thoracic Society/European Respiratory Society statement: standards for the diagnosis and management of individuals with alpha-1 antitrypsin deficiency. Am J Respir Crit Care Med. 2003;168(7): 818-900.

44. Bowlus CL, Willner I, Zern MA, et al. Factors associated with advanced liver disease in adults with alpha-1-antitrypsin deficiency. Clin Gastroenterol Hepatol. 2005;3(4):390-396.

45. Kemmer N, Kaiser T, Zacharias V, Neff GW. Alpha-1-antitrpysin deficiency: outcomes after liver transplantation. Transplant Proc. 2008; 40(5):1492-1494.

46. McElvaney NG, Stoller JK, Buist AS, et al. Baseline characteristics of enrollees in the National Heart, Lung and Blood Institute Registry of alpha 1-antitrypsin deficiency. Alpha 1-Antitrypsin Deficiency Registry Study Group. Chest. 1997;111(2):394-403

47. Stoller JK, Smith P, Yang P, Spray J. Physical and social impact of alpha 1-antitrypsin deficiency: results of a survey. Cleve Clin J Med. 1994; 61(6):461-467.

48. Stoller JK, Sandhaus RA, Turino G, Dickson R, Rodgers K, Strange C. Delay in diagnosis of alphal-antitrypsin deficiency: a continuing problem. Chest. 2005;128(4):1989-1994.

49. Janus ED, Phillips NT, Carrell RW. Smoking, lung function, and alpha 1-antitrypsin deficiency. Lancet. 1985;1(8421):152-154.

50. Dowson LJ, Guest PJ, Stockley RA. Longitudinal changes in physiological, radiological, and health status measurements in alpha(1)antitrypsin deficiency and factors associated with decline. Am J Respir Crit Care Med. 2001;164(10 pt 1):1805-1809.

51. Mayer AS, Stoller JK, Bucher BB, et al. Occupational exposure risks in individuals with $\mathrm{PI}$ Z $\mathrm{Z}$ alpha(1)-antitrypsin deficiency. Am J Respir Crit Care Med. 2000;162(2 pt 1):553-538.

52. Bamforth FJ, Kalsheker NA. Alpha 1 antitrypsin deficiency due to Pi null: clinical presentation and evidence for molecular heterogeneity. J Med Genet. 1988;25(2):83-87.

53. Stockley RA. Measurement of soluble proteins in lung secretions. Thorax. 1984;39(4):241-247.

54. Elliott PR, Bilton D, Lomas DA. Lung polymers in Z $\alpha$-1-antitrypsin deficiency-related emphysema. Am J Respir Cell Mol Biol. 1998;18(5): 670-674.

55. Mulgrew AT, Taggart CC, Lawless MW, et al. Z $\alpha$-1-antitrypsin polymerizes in the lung and acts as a neutrophil chemoattractant. Chest. 2004;125(5):1952-1957.

56. Alam S, Li Z, Janciauskiene S, Mahadeva R. Oxidation of Z \{alpha $\} 1$ antitrypsin by cigarette smoke induces polymerisation: a novel mechanism of early-onset emphysema. Am J Respir Cell Mol Biol. 2010. [Epub ahead of print].

57. Parmar JS, Mahadeva R, Reed BJ, et al. Polymers of alpha(1)-antitrypsin are chemotactic for human neutrophils: a new paradigm for the pathogenesis of emphysema. Am J Respir Cell Mol Biol. 2002;26(6): 723-730.

58. Woolhouse IS, Bayley DL, Stockley RA. Sputum chemotactic activity in chronic obstructive pulmonary disease: effect of alpha(1)-antitrypsin deficiency and the role of leukotriene $\mathrm{B}(4)$ and interleukin 8. Thorax. 2002;57(8):709-714.

59. Hubbard RC, Fells G, Gadek J, Pacholok S, Humes J, Crystal RG. Neutrophil accumulation in the lung in alpha 1-antitrypsin deficiency. Spontaneous release of leukotriene B4 by alveolar macrophages. J Clin Invest. 1991;88(3):891-897.

60. Ogushi F, Fells GA, Hubbard RC, Straus SD, Crystal RG. Z-type alpha 1-antitrypsin is less competent than M1-type alpha-1 antitrypsin as an inhibitor of neutrophil elastase. J Clin Invest. 1987;80(5): 1366-1374.

61. Johnson D, Travis J. The oxidative inactivation of human alpha-1proteinase inhibitor. Further evidence for methionine at the reactive center. J Biol Chem. 1979;254(10):4022-4026. 
62. Li Z, Alam S, Wang J, Sandstrom CS, Janciauskiene S, Mahadeva R. Oxidized alpha1-antitrypsin stimulates the release of monocyte chemotactic protein-1 from lung epithelial cells: potential role in emphysema. Am J Physiol Lung Cell Mol Physiol. 2009;297(2):L388-L400.

63. Petrache I, Fijalkowska I, Medler TR, et al. Alpha-1 antitrypsin inhibits caspase-3 activity, preventing lung endothelial cell apoptosis. Am $J$ Pathol. 2006;169(4):1155-1166.

64. Blanco I, Lara B, de Serres F. Efficacy of alpha1-antitrypsin augmentation therapy in conditions other than pulmonary emphysema. Orphanet J Rare Dis. 2011;6:14.

65. Wilcke JT, Dirksen A. The effect of inhaled glucocorticosteroids in emphysema due to alpha1-antitrypsin deficiency. Respir Med. 1997; 91(5):275-279.

66. Corda L, Bertella E, La Piana GE, Boni E, Redolfi S, Tantucci C. Inhaled corticosteroids as additional treatment in alpha-1-antitrypsin-deficienyrelated COPD. Respiration. 2008;76(1):61-68.

67. Fishman A, Martinez F, Naunheim, et al. A randomized trial comparing lung-volume-reduction surgery with medical therapy for severe emphysema. N Engl J Med. 2003;348(21):2059-2073.

68. Dauriat G, Mal H, Jebrak G, et al. Functional results of unilateral lung volume reduction surgery in alpha, -antitrypsin deficient patients. Int $J$ Chron Obstruct Pulmon Dis. 2006;1(2):201-206.

69. Remund KF, Bartosik W, Wood AE, Egan JJ. Endobronchial valve treatment in patients with advanced emphysema and alpha-1-antitrypsin deficiency. Thorax. 2008;63(Suppl VII):A12.

70. The International Society for Heart and Lung Transplantation. Available at: http://www.ishlt.org/registries. Accessed March 2, 2011.

71. Wewers MD, Casolaro MA, Sellers SE, et al. Replacement therapy for alpha 1-antitrypsin deficiency associated with emphysema. $N$ Engl $J$ Med. 1987;316(17):1055-1062.

72. Kueppers $\mathrm{F}$. The role of augmentation therapy in alpha-1 antitrypsin deficiency. Curr Med Res Opin. 2011;27(3):579-588.

73. Silverman EK, Sandhaus RA. Clinical Practice: alpha1-antitrypsin deficiency. $N$ Engl J Med. 2009;360(26):2749-2757.

74. Stoller JK, Fallat R, Schluchter MD, et al. Augmentation therapy with alpha1-antitrypsin: patterns of use and adverse events. Chest. 2003; 123(5):1425-1434.

75. Schmidt EW, Rasche B, Ulmer WT, et al. Replacement therapy for alpha1-protease inhibitor deficiency in PiZ subjects with chronic obstructive disease. Am J Med. 1988;84(6A):63-69.

76. Campos MA, Wanner A, Zhang G, Sandhaus RA. Trends in the diagnosis of symptomatic patients with $\alpha_{1}$-antitrypsin deficiency between 1968 and 2003. Chest. 2005;128(3):1179-1186.

77. Feedback on Cochrane review; see ref 20. Available at: http://onlinelibrary.wiley.com/o/cochrane/clsysrev/articles/CD007851/frame.html. Accessed August 4, 2011.

78. Hutchinson DC, Hughes MD. Alpha-1-antitrypsin replacement therapy: will its efficacy ever be proved? Eur Respir J. 1997;10(10):2191-2193.

79. Schluchter MD, Stoller JK, Barker AF, et al. Feasibility of a clinical trial of augmentation therapy for $\alpha_{1}$-antitrypsin deficiency. Am J Respir Crit Care Med. 2000;161(3 pt 1):796-801.

80. Seersholm N, Wencker M, Banik N, et al. Does $\alpha_{1}$-antitrypsin augmentation therapy slow the annual decline in $\mathrm{FEV}_{1}$ in patients with severe hereditary $\alpha_{1}$-antitrypsin deficiency? Wissenschaftliche Arbeitsgemeinschaft zur Therapie von Lungenerkrankungen (WATL) alpha1-AT study group. Eur Respir J. 1997;10(10):2260-2263.

81. The Alpha-1-Antitrypsin Deficiency Registry Study Group. Survival and $\mathrm{FEV}_{1}$ decline in individuals with severe deficiency of alpha1-antitrypsin. Am J Respir Crit Care Med. 1998;158(1):49-59.

82. Wencker M, Fuhrmann B, Banik N, Konietzko N. Longitudinal follow-up of patients with $\alpha_{1}$-protease inhibitor deficiency before and during therapy with IV $\alpha_{1}$-protease inhibitor. Chest. 2001;119(3): 737-744.

83. Tonelli AR, Rouhani F, Li N, Schreck P, Brantly ML. Alpha-1-antitrypsin augmentation therapy in deficient individuals enrolled in the Alpha-1 Foundation DNA and Tissue Bank. Int J Chron Obstruct Pulmon Dis. 2009;4:443-452.
84. Dirksen A, Dijkman JH, Madsen F, et al. A randomized clinical trial of $\alpha_{1}$-antitrypsin augmentation therapy. Am J Respir Crit Care Med. 1999;160(5 pt 1):1468-1472.

85. Hubbard RC, Sellers S, Czerski D, Stephens L, Crystal RG. Biochemical efficacy and safety of monthly augmentation therapy for alpha 1-antitrypsin deficiency. JAMA. 1988;260(9):1259-1264.

86. Dirksen A, Piitulainen E, Parr DG, et al. Exploring the role of CT densitometry: a randomised study of augmentation therapy in $\alpha_{1}$-antitrypsin deficiency. Eur Respir J. 2009;33(6):1345-1353.

87. Zemaira in Subjects With Emphysema Due to Alpha1-Proteinase Inhibitor (API) Deficiency. ClinicalTrials.gov Identifier: NCT00261833.

88. Chapman KR, Bradi AC, Paterson D, et al. Slower lung function decline during augmentation therapy in patients with alpha 1-antitrypsin efficiency (A1ATD): results from the Canadian AIR registry. Proc Am Thorac Soc. 2005:A808.

89. Chapman KR, Stockley RA, Dawkins C, et al. Augmentation therapy for alpha1-antitrypsin deficiency: a meta-analysis. COPD. 2009;6(3): $177-184$.

90. Stockley RA, Parr DG, Piitulainen E, et al. Therapeutic efficacy of alpha-1 antitrypsin augmentation therapy on the loss of lung tissue: an integrated analysis of 2 randomised clinical trials using computed tomography densitometry. Respir Res. 2010;11:136.

91. Lieberman J. Augmentation therapy reduces frequency of lung infections in antitrypsin deficiency: a new hypothesis with supporting data. Chest. 2000;118(5):1480-1485.

92. Campos MA, Alazemi S, Zhang G, et al. Exacerbations in subjects with alpha-1 antitrypsin deficiency receiving augmentation therapy. Respir Med. 2009;103(10):1532-1539.

93. Stockley RA, Bayley DL, Unsal I, Dowson LJ. The effect of augmentation therapy on bronchial inflammation in $\alpha_{1}$-antitrypsin deficiency. Am J Respir Crit Care Med. 2002;165(11):1494-1498.

94. Dirksen A, Friis M, Olesen KP Skovgaard LT, Sorensen K. Progress of emphysema in severe $\alpha_{1}$-antitrypsin deficiency as assessed by annual CT. Acta Radiol. 1997;38(5):826-832.

95. Voulgari F, Cummins P, Gardecki TI, Beeching NJ, Stone PC, Stuart J. Serum levels of acute phase and cardiac proteins after myocardial infarction, surgery and infection. Br Heart J. 1982;48(4):352-356.

96. Schwarzenburg SJ, Sharp HL, Berry SA, Manthei RD, Seelig S. Hormonal regulation of serum alpha 1-antitrypsin and hepatic alpha 1-antitrypsin mRNA in rats. Biochem Biophys Res Commun. 1987; 147(3):936-941.

97. Mallya M, Phillips RL, Saldanha SA, et al. Small molecules block the polymerization of $\mathrm{Z} \alpha_{1}$-antitrypsin and increase the clearance of intracellular aggregates. $J$ Med Chem. 2007;50(22):5357-5363.

98. Mahadeva R, Chang WS, Dafforn T, et al. Heteropolymerization of S, I, and Z $\alpha_{1}$-antitrypsin and liver cirrhosis. J Clin Invest. 1999; 103(7):999-1006.

99. Miranda E, Perez J, Hadzic N, et al. A novel monoclonal antibody to characterize pathogenic polymers in liver disease associated with $\alpha_{1}$-antitrypsin deficiency. Hepatology. 2010;52(3):1078-1088.

100. Poller W, Merklein F, Schneider-Rasp S, et al. Molecular characterization of the defective alpha 1-antitrypsin alleles PI Mwurzburg (Pro369Ser), Mheerlen (Pro369 Leu), and Q0lisbon (Thr68Ile). Eur J Hum Genet. 1999;7(3):321-331.

101. Fraizer GC, Harrold TR, Hofker MH, Cox DW. In-frame single codon deletion in the Mmalton deficiency allele of $\alpha_{1}$-antitrypsin. Am J Hum Genet. 1989;44(6):894-902.

102. Curiel DT, Vogelmeier C, Hubbard RC, Stier LE, Crystal RG. Molecular basis of alpha 1-antitrypsin deficiency and emphysema associated with the alpha 1-antitrypsin Mmineral springs allele. Mol Cell Biol. 1990;10(1):47-56.

103. Matsunaga E, Shiokawa S, Nakamura H, Maruyama T, Tsuda K, Fukumaki Y. Molecular analysis of the gene of the alpha 1-antitrypsin deficiency variant, Mnichinan. Am J Hum Gene. 1990;46(3):602-612.

104. Faber J-P, Poller W, Weidinger S, et al. Identification and DNA sequence analysis of 15 new alpha- 1 antitrypsin variants, including 2 PiQO alleles and one deficient PiM allele. Am J Hum Genet. 1994; 55(6):1113-1121. 
105. Takahashi H, Nukiwa T, Satoh K, et al. Characterization of the gene and protein of the alpha 1-antitrypsin "deficiency" allele Mprocida. J Biol Chem. 1988;263(30):15528-15534.

106. Jardi R, Rodriguez-Frias F, Lopez-Talavera JC, et al. Characterization of the new alpha-1-antitrypsin-deficient PI M-type allele, PI M(vall d'hebron) (Pro(369)-->Ser). Hum Hered. 2000;50(5):320-321.

107. Coni P, Pili E, Convertino G, et al. MVarallo: a new M(Like) alpha 1-antitrypsin-deficient allele. Diagn Mol Pathol. 2003;12(4):237-239.

108. Owen MC, Brennan SO, Lewis JH, Carrell RW. Mutation of antitrypsin to antithrombin. Alpha 1-antitrypsin Pittsburgh (358 Met leads to Arg), a fatal bleeding disorder. $N$ Engl J Med. 1983;309(12):694-698.

109. Faber JP, Weidinger S, Goedde HW, Ole K. The deficient alpha-Iantitrypsin phenotype PI P is associated with an A-to-T transversion in exon III of the gene. Am J Hum Genet. 1989;45(1):161-163.

110. Graham A, Kalsheker NA, Newton CR, Bamforth FJ, Powell SJ, Markham AF. Molecular characterisation of three alpha-1-antitrypsin deficiency variants: proteinase inhibitor (Pi) nullcardiff (Asp256---Val); PiMmalton (Phe51----deletion) and PiI (Arg39----Cys). Hum Genet. 1989;84(1):55-58.

111. Hildesheim J, Kinsley G, Bissell M, Pierce J, Brantly M. Genetic diversity from a limited repertoire of mutations on different common allelic backgrounds: alpha 1-antitrypsin deficiency variant Pduarte. Hum Mutat. 1993;2(3):221-228.

112. Coli A, Bigotti G. Alpha-1-antitrypsin protease inhibitor SZ phenotype and liver cirrhosis. Appl Pathol. 1989;7(1):54-60.

113. Holme J, Stockley RA. CT scan appearance, densitometry, and health status in protease inhibitor SZ alpha1-antitrypsin deficiency. Chest. 2009;136(5):1284-1290.

114. Blanco I, Bustillo EF, Rodriguez MC. Distribution of $\alpha 1$-antitrypsin PI S and PI Z frequencies in countries outside Europe: a meta-analysis. Clin Genet. 2001;60(6):431-441.

115. Yuasa I, Sugimoto Y, Ichinose M, et al. PI*S(iiyama), a deficiency gene of alpha 1-antitrypsin: evidence for the occurrence in western Japan. Jpn J Hum Genet. 1993;38(2):185-191.

116. Holmes MD, Brantly ML, Fells GA, Crystal RG. Alpha 1-antitrypsin Wbethesda: molecular basis of an unusual alpha 1-antitrypsin deficiency variant. Biochem Biophys Res Commun. 1990;170(3):1013-1020.

117. Jardi R, Rodriguez F, Miravitlles M, et al. Identification and molecular characterization of the new alpha-1-antitrypsin deficient allele PI Y barcelona (Asp256-->Val and Pro391-->His). Mutations in brief no.174. Online. Hum Mutat. 1998;12(3):213.

118. Sørheim IC, Bakke P, Gulsvik A, et al. $\alpha_{1}$-antitrypsin protease inhibitor MZ heterozygosity is associated with airflow obstruction in two large cohorts. Chest. 2010;138(5):1125-1132.

119. Graziadei IW, Joseph JJ, Wiesner RH, Therneau TM, Batts KP, Porayko MK. Increased risk of chronic liver failure in adults with heterozygous alpha1-antitrypsin deficiency. Hepatology. 1998;28(4):1058-1063.

120. Weidinger S, Jahn W, Cujnik F, Schwarzfischer F. Alpha-1-antitrypsin: evidence for a fifth PI M subtype and a new deficiency allele PI*Z augsburg. Hum Genet. 1985;71(1):27-29.

121. Whitehouse DB, Abbott CM, Lovegrove JU, et al. Genetic studies on a new deficiency gene (PI*Ztun) at the PI locus. $J$ Med Genet. 1989;26(12):744-749.
122. Graham A, Kalsheker NA, Bamforth FJ, Newton CR, Markham AF. Molecular characterisation of two alpha-1-antitrypsin deficiency variants: proteinase inhibitor (Pi) Null(Newport) (Gly115----Ser) and (Pi) Z Wrexham (Ser-19----Leu). Hum Genet. 1990;85(5):537-540.

123. Satoh K, Nukiwa T, Brantly M, et al. Emphysema associated with complete absence of alpha 1- antitrypsin in serum and the homozygous inheritance [corrected] of a stop codon in an alpha 1-antitrypsin-coding exon. Am J Hum Genet. 1988;42(1):77-83.

124. Fraizer GC, Harrold TR, Hofker MH, Cox DW. In-frame single codon deletion in the Mmalton deficiency allele of alpha 1-antitrypsin. Am J Hum Genet. 1989;44(6):894-902.

125. Zorzetto M, Ferrarotti I, Campo I, et al. Identification of a novel alpha1-antitrypsin null variant (Q0Cairo). Diagn Mol Pathol. 2005; 14(2):121-124.

126. Brantly M, Lee JH, Hildesheim J, et al. Alpha1-antitrypsin gene mutation hot spot associated with the formation of a retained and degraded null variant. Am J Respir Cell Mol Biol. 1997;16(3):225-231.

127. Nukiwa T, Takahashi H, Brantly M, Courtney M, Crystal RG. alpha 1-Antitrypsin nullGranite Falls, a nonexpressing alpha 1-antitrypsin gene associated with a frameshift to stop mutation in a coding exon. J Biol Chem. 1987;262(25):11999-12004.

128. Sifers RN, Brashears-Macatee S, Kidd VJ, Muensch H, Woo SL. A frameshift mutation results in a truncated alpha 1-antitrypsin that is retained within the rough endoplasmic reticulum. J Biol Chem. 1988; 263(15):7330-7335.

129. Takahashi H, Crystal RG. Alpha 1-antitrypsin Null (isola di procida): an alpha 1-antitrypsin deficiency allele caused by deletion of all alpha 1-antitrypsin coding exons. Am J Hum Genet. 1990;47(3):403-413.

130. Frazier GC, Siewertsen MA, Hofker MH, Brubacher MG, Cox DW. A null deficiency allele of alpha 1-antitrypsin, QOludwigshafen, with altered tertiary structure. J Clin Invest. 1990;86(6):1878-1884.

131. Curiel D, Brantly M, Curiel E, Stier L, Crystal RG. Alpha-1-antitrypsin deficiency caused by the alpha-1-antitrypsin null ${ }_{\text {mattawa }}$ gene. J Clin Invest. 1989;83(4):1144-1152.

132. Vaz Rodrigues L, Costa F, Marques P, Mendonça C, Rocha J, Seixas S. Severe $\alpha-1$ antitrypsin deficiency caused by Q0(Ourém) allele: clinical features, haplotype characterization and history. Clin Genet. 2011. [Epub ahead of print].

133. Poller W, Faber JP, Weidinger S, Olek K. DNA polymorphisms associated with a new alpha 1-antitrypsin PIQ0 variant (PIQ0riedenburg). Hum Genet. 1991;86(5):522-524.

134. Lee J, Novoradovskaya N, Rundquist B, Rewine J, Saltini C, Brantly M. Alpha-1-antitrypsin nonsense mutation associated with retained truncated protein and reduced mRNA. Mol Genet Metab. 1998;63(4):270-280.

135. Laubach VE, Ryan WJ, Brantly M. Characterization of a human alpha 1-antitrypsin null allele involving aberrant mRNA splicing. Hum Mol Genet. 1993;2(7):1001-1005.

136. Lomas DA, Belorgey D, Mallya M, et al. Molecular mousetraps and the serpinopathies. Biochem Soc Trans. 2005;33(pt 2):321-330.

137. Lomas DA, Finch JT, Seyama K, Nukiwa T, Carrell RW. Alpha1antitrypsin Siiyama (Ser53Phe). Further evidence for intracellular loopsheet polymerization. J Biol Chem. 1993;268(21):15333-15335.

\section{Publish your work in this journal}

Drug Design, Development and Therapy is an international, peerreviewed open-access journal that spans the spectrum of drug design and development through to clinical applications. Clinical outcomes, patient safety, and programs for the development and effective, safe, and sustained use of medicines are a feature of the journal, which

\section{Dovepress}

has also been accepted for indexing on PubMed Central. The manuscript management system is completely online and includes a very quick and fair peer-review system, which is all easy to use. Visit http://www.dovepress.com/testimonials.php to read real quotes from published authors. 